\title{
Temperature trends in Hong Kong from a seasonal perspective
}

\author{
H. S. Chan*, M. H. Kok, T. C. Lee \\ Hong Kong Observatory, 134A Nathan Road, Tsimshatsui, Kowloon, Hong Kong SAR
}

\begin{abstract}
We examined the seasonal trends of mean and extreme temperatures in Hong Kong using data from 1885-2010. The analysis revealed that the daily maximum temperature $\left(\mathrm{T}_{\mathrm{Max}}\right)$ daily mean temperature $\left(\mathrm{T}_{\text {Mean }}\right)$, and daily minimum temperature $\left(\mathrm{T}_{\mathrm{Min}}\right)$ of Hong Kong had a significant long-term increasing trend in all 4 seasons and that the warming trend was more prominent in winter and spring. The relatively higher rate of increase in temperatures in winter and spring could be attributed to local urbanization effects and the weakening of the East Asian winter monsoon in the last few decades. For extreme indices, we observed a significant increase in the hot indices (TN90p and TX90p) and a significant decrease in the cold indices (TX10p and TN10p) in all seasons. The seasonal variations in the heating and cooling degree-days (HDD and CDD) also indicated that CDD in spring, summer, and autumn had a significant increasing trend, while HDD in spring, autumn and winter had a decreasing trend. Analysis of the hot and cool periods in Hong Kong showed a significant decreasing (increasing) trend in the number of cool (hot) days. Also, the cool (hot) period has become shorter (longer) over the last century.
\end{abstract}

KEY WORDS: Hong Kong $\cdot$ Seasonal temperature trends $\cdot$ Heating degree day $\cdot$ Cooling degree day $\cdot$ Extreme indices

Resale or republication not permitted without written consent of the publisher

\section{INTRODUCTION}

Climate change is one of the major challenges facing humans in the 21st century and has become an important topic globally in recent years. Since the 18th century, rapid development of economic and industrial activities has led to increased use of energy and resources. The rise in anthropogenic greenhouse gas concentrations in the atmosphere, particularly due to the burning of fossil fuels, enhances the greenhouse effect and alters the Earth's energy balance (Hansen et al. 1981, Zwiers \& Weaver 2000, Solomon et al. 2009, Lacis et al. 2010), contributing to global climate change. One of the key signals of climate change is the increase in global mean surface temperature. The 20th century has seen a significant longterm increasing trend in the global mean surface temperature, with a rise of about $0.74^{\circ} \mathrm{C}$ from 1906 to 2005 (IPCC 2007a). The warming has continued into the first decade of the 21st century. According to the World
Meteorological Organization (WMO), 2010 ranked with 1998 and 2005 as the warmest year on record since the 1880s, and the decade 2001-2010 was also the warmest decade on record (WMO 2011a). In 2007, the Fourth Assessment Report of the United Nations Intergovernmental Panel on Climate Change (IPCC) concluded that warming of the climate system is unequivocal, and most of the observed increase in globally averaged temperatures since the mid-20th century is very likely, i.e. more than $90 \%$ certain, due to the observed increase in man-made greenhouse gas concentrations (IPCC 2007a). The shifting of the mean temperature could also cause changes in the frequency of occurrence of extreme temperature events (such as heatwaves and cold spells) in some regions (Houghton 2009, Christidis et al. 2011, WMO 2011b), leading to significant socio-economic impacts (Frich et al. 2002, IPCC 2007b, WMO 2009).

In addition to anthropogenic greenhouse gases, other first-order human climate forcing (such as aero- 
sols, land use changes, urbanization) may also have significant effects on the Earth's climate (Ren et al. 2008, Pielke et al. 2009, Stott et al. 2010, Jones et al. 2011). These forcings are spatially heterogeneous and may have temporal/seasonal variations. Together with local/regional topography and climatic systems (e.g. monsoons), they can bring about regional and seasonal variations in the trends of climate change.

In China, climate change has been studied intensively over the last 2 decades. A number of studies have been carried out to establish a homogeneous temperature record in order to assess the long-term temperature variations in China over the last $100 \mathrm{yr}$ (Wang et al. 2004, Zhai et al. 2004, Ding et al. 2007, Li \& Yan 2009, Tang et al. 2010). Similar to the global trend, the country-averaged annual mean surface temperature in China has increased significantly in the 20th century, with a trend of $0.08^{\circ} \mathrm{C}$ decade $^{-1}$ for the period $1905-2001$ and reaching $0.22^{\circ} \mathrm{C}$ decade $^{-1}$ for the period 1951-2001 (Ding et al. 2007). Tang et al. (2010) also conducted a comparative analysis of surface temperature series for the period 1906-2005, showing an increase in annual mean $( \pm \mathrm{SE})$ temperature of $0.78 \pm 0.27^{\circ} \mathrm{C}$ during the century of study in China. The analysis by Li \& Yan (2009) using the 'Multiple Analysis of Series for Homogenization' software package and 549 National Standard Stations in China showed a mean warming trend of $0.193^{\circ} \mathrm{C}$ decade $^{-1}$ during 1960-2008. For seasonal patterns, all 4 seasons show a warming trend over most parts of China, the warming being more profound in winter, especially for northern China (Ding et al. 2007, Li \& Yan 2009, Wei \& Feng 2009).

Urbanization, including land use changes, dense building developments, heat emissions, and human activities, has a great impact on local climate. One of the best-known effects of urbanization is the urban heat island (UHI) effect. He et al. (2007) studied the temperature trends of urban and non-urban stations between 1991 and 2000 and concluded that the UHI due to changes in land use is significant at urban stations. Li et al. (2004) analyzed homogenized annual mean surface air temperature data from 1954-2002 in China and found that at most stations located in a city with a population over 100000 , the temperature series were inevitably affected by the UHI effect. In heavily populated regions, like the Yangtze River Valley and South China, UHIs have a significant impact on temperature compared to other regions over China. Zhou et al. (2004) and Dou \& Zhao (2011) also concluded that UHIs contribute significantly to increasing temperature over South China. Ren et al.
(2007) studied urbanization-induced warming for Beijing and Wuhan from 1961-2000 and 1981-2000, respectively. The warming due to urbanization was significant and accounted for $>40 \%$ in both cities. In southern China, recent studies have also revealed a long-term increase in the annual mean temperature trend in the region under the effects of global warming and urbanization (Leung et al. 2004, Lee et al. 2006, Guangdong Provincial Meteorological Bureau 2007, Fong et al. 2010, Ginn et al. 2010, Dou \& Zhao 2011).

The Hong Kong Observatory has been conducting meteorological observations in Hong Kong for over 120 years. The meteorological data collected over the years serve as an important basis for monitoring climate change in Hong Kong. Analysis of the annual mean temperature in the region has shown a longterm increasing trend under the effect of global warming and local urbanization (Lee et al. 2006, Ginn et al. 2010). For extreme temperature events, recent studies revealed that the extreme daily minimum and maximum temperatures in Hong Kong exhibited statistically significant long-term rising trends from 1885-2008 (Wong et al. 2010, Lee et al. 2011).

Previous studies on the temperature trends of Hong Kong have been based mainly on the annual mean temperatures or extreme values on an annual basis. Therefore, it is meaningful to investigate the seasonal trends in order to provide a better understanding of the characteristics of climate change in Hong Kong from a seasonal perspective. In this study, variations in the maximum, mean, and minimum temperatures as well as a set of extreme temperature indices in Hong Kong from 1885-2010 were analyzed to identify tendencies in different months and seasons. We also examined changes in the length of hot and cool durations in Hong Kong.

\section{METHODS}

\subsection{Meteorological observations}

Apart from a break during World War II from 1940-1946, the Hong Kong Observatory has been conducting temperature measurements continuously at its headquarters (HKOHq) located in an urban area since 1885. In this study, we used the daily and monthly mean temperatures at HKOHq from 18852010. Metadata of the temperature measurement at $\mathrm{HKOHq}$ is documented in relevant HKO publications (Lee et al. 2006, Hong Kong Observatory 2011). The mean temperature data of Macao from 1951-2002 
were also used in this study to assess the urbanization effect in Hong Kong. The homogeneity of Macao temperature was examined by Fong et al. (2010). They concluded that there is no significant data discontinuity due to the 2 site relocations in 1966 and 1996. Fig. 1 shows the relative locations of Hong Kong and Macao.

To calculate the observed monthly mean air temperature at the $850 \mathrm{hPa}$ level in Hong Kong, we used daily 00 and $12 \mathrm{Z}$ upper air sounding data from the King's Park Meteorological Station (located about $1 \mathrm{~km}$ from $\mathrm{HKOHq}$ ) from 1971-2010. For upper level reanalysis data, monthly $850 \mathrm{hPa}$ air temperature grid-point data in the vicinity of Hong Kong (20 to $30^{\circ} \mathrm{N}$ and 105 to $120^{\circ} \mathrm{E}$ ) from $1971-2010$ were retrieved from the U.S. National Centers for Environment Prediction - National Center for Atmospheric Research (NCEP-NCAR) Re-analysis 1 data (Kalnay et al. 1996). Unless otherwise stated, the observed temperatures in Hong Kong refer to the corresponding values at $\mathrm{HKOHq}$ in this study. Also, spring refers to the period from March-May (MAM), summer from June-August (JJA), autumn from September-November (SON), and winter from December-February (DJF) (Leung et al. 2004).

\subsection{Extreme temperature indices}

In order to rationalize and standardize the expressions for extreme weather events so that individuals, countries, and regions can calculate the related indices in the same way such that their analyses can fit together seamlessly, the Expert Team on Climate Change Detection, Monitoring and Indices (ETCCDMI) working under the joint WMO Commission for Climatology/World Climate Research Programme Climate Variability and Predictability (CLIVAR) pro-

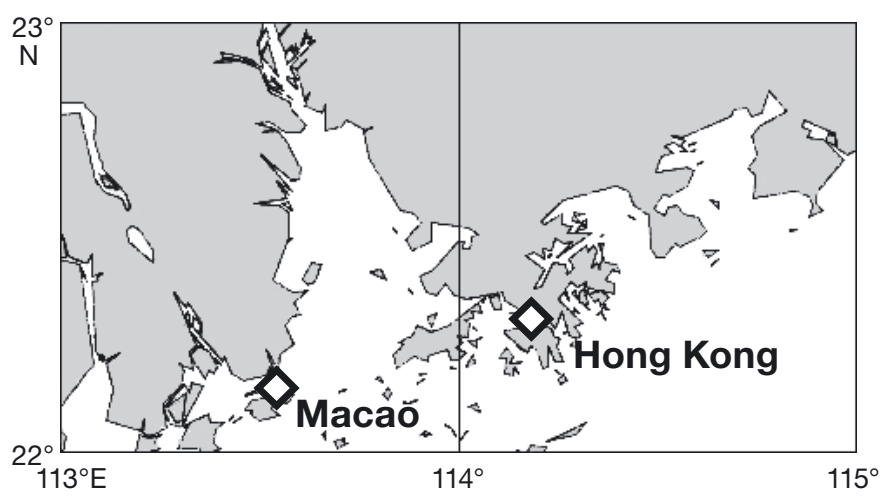

Fig. 1. Stations at the Hong Kong Observatory Headquarters and Macao ject (Peterson et al. 2001, Peterson 2005) has developed a suite of indices for the purpose. Four extreme temperature indices, namely TN10p, TX10p, TN90p, and TX90p, were adopted from ETCCDMI (http:// cccma.seos.uvic.ca/ETCCDI/indices.shtml) in this study with appropriate modifications to suit the local climate to illustrate the trend and significance of extreme temperature events. TN10p denotes the percentage of time with daily minimum temperatures lower than the 10th percentile of minimum temperatures calculated for each calendar day (with reference to the period 1971-2000) using a running $5 \mathrm{~d}$ window. This is a measure of the percentage of nights with unseasonably low temperature in a year. Similarly, TX10p denotes the percentage of days with unseasonably low temperature. TN90p (TX90p) corresponds to the percentage of nights (days) with unseasonably high temperature in a year. Generally speaking, TN90p and TX90p can be considered as 'hot indices' and TN10p and TX10p as 'cold indices.' Detailed definitions of the indices have been well documented in other publications (Wong et al. 2010, Lee et al. 2011) and are not repeated here.

\subsection{Cooling degree-days and heating degree-days}

Two climatic indices, namely cooling degree-days (CDD) and heating degree-days (HDD), were adopted in this study to examine how often and to what extent cooling and heating energy consumption will be required during a particular period (Eto 1988, Lam 1995, Day \& Karayiannis 1999, Valor et al. 2001). Monthly CDD and HDD are the monthly totals of the daily differences between daily mean air temperature and the base temperature. The larger the value of CDD (HDD), the more cooling (heating) is required.

Monthly CDD and HDD are calculated based on the following formulas:

$$
\begin{aligned}
& \mathrm{CDD}=\sum_{i=1}^{M}\left(T_{i}-T_{\text {base }}\right) \quad\left(\text { for } T_{\text {base }}>T_{i},\left[T_{i}-T_{\text {base }}\right]=0\right) \\
& \mathrm{HDD}=\sum_{i=1}^{M}\left(T_{\text {base }}-T_{i}\right) \quad\left(\text { for } T_{i}>T_{\text {base }},\left[T_{\text {base }}-T_{i}\right]=0\right)
\end{aligned}
$$

where $M$ is the number of days in a month, $T_{i}$ is the daily mean temperature of day $i$, and $T_{\text {base }}$ is the base temperature.

In this study, the base temperatures followed those of the Ministry of Housing and Urban-Rural Development in China (2005), which defines the base temperatures as 26.0 and $18.0^{\circ} \mathrm{C}$ for CDD and HDD, respectively. 


\subsection{Cool and hot days}

To assess the possible changes in the length of hot and cool periods in Hong Kong, 'cool' and 'hot' days for Hong Kong were defined in this study as follows. 'Cool (hot) day' is defined as a day with daily mean temperature $\leq 18.8^{\circ} \mathrm{C}\left(\geq 27.7^{\circ} \mathrm{C}\right)$, which is the 25th (75th) percentile of daily mean temperature distribution during the climatological reference period 1971-2000.

\subsection{Linear regression analysis}

Linear regression analysis was adopted to determine the trends in the extreme indices. By assuming a normal distribution of the temperature data, the $t$ test was applied to assess the statistical significance of the trends at the $5 \%$ significance level (Karl et al. 1993, Easterling et al. 1997, von Storch \& Zwiers 1999).
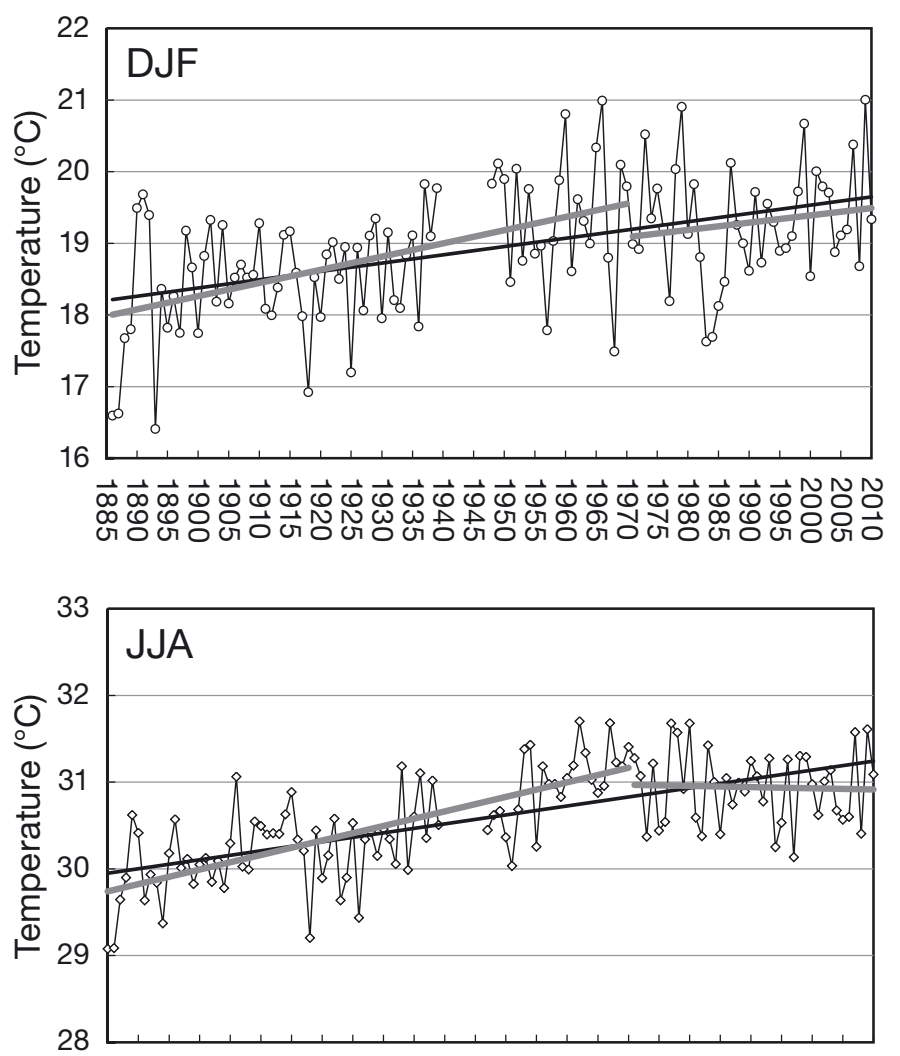

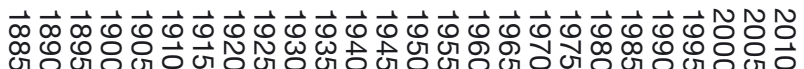

\section{RESULTS AND DISCUSSION}

\subsection{Seasonal trends of maximum, mean, and minimum temperatures}

Figs. 2-4 respectively show the time series of the annual mean of the daily maximum temperature $\left(\mathrm{T}_{\text {Max }}\right)$, daily mean temperature $\left(\mathrm{T}_{\text {Mean }}\right)$, and daily minimum temperature $\left(\mathrm{T}_{\text {Min }}\right)$ of Hong Kong in the 4 seasons from 1885-2010. The corresponding linear trends of $\mathrm{T}_{\text {Max }}, \mathrm{T}_{\text {Mean }}$, and $\mathrm{T}_{\mathrm{Min}}$ in the 4 seasons from 1885-2010 are tabulated in Table 1. $\mathrm{T}_{\text {Max }}, \mathrm{T}_{\text {Mean }}$, and $\mathrm{T}_{\text {Min }}$ show an increasing trend which was statistically significant at the $5 \%$ level in all 4 seasons. The increasing trends of $\mathrm{T}_{\text {Max }}, \mathrm{T}_{\text {Mean, }}$ and $\mathrm{T}_{\text {Min }}$ are more prominent in winter and spring than in summer and autumn. The trends for the sub-periods 1885-1970 and 1971-2010 are also shown in Figs. 2-4. For $T_{\text {Min }}$ the rate of increase after 1970 is noticeably faster than that of 1885-1970. However, for $\mathrm{T}_{\mathrm{Max}}$, the increasing trend mainly happened before the 1970s.
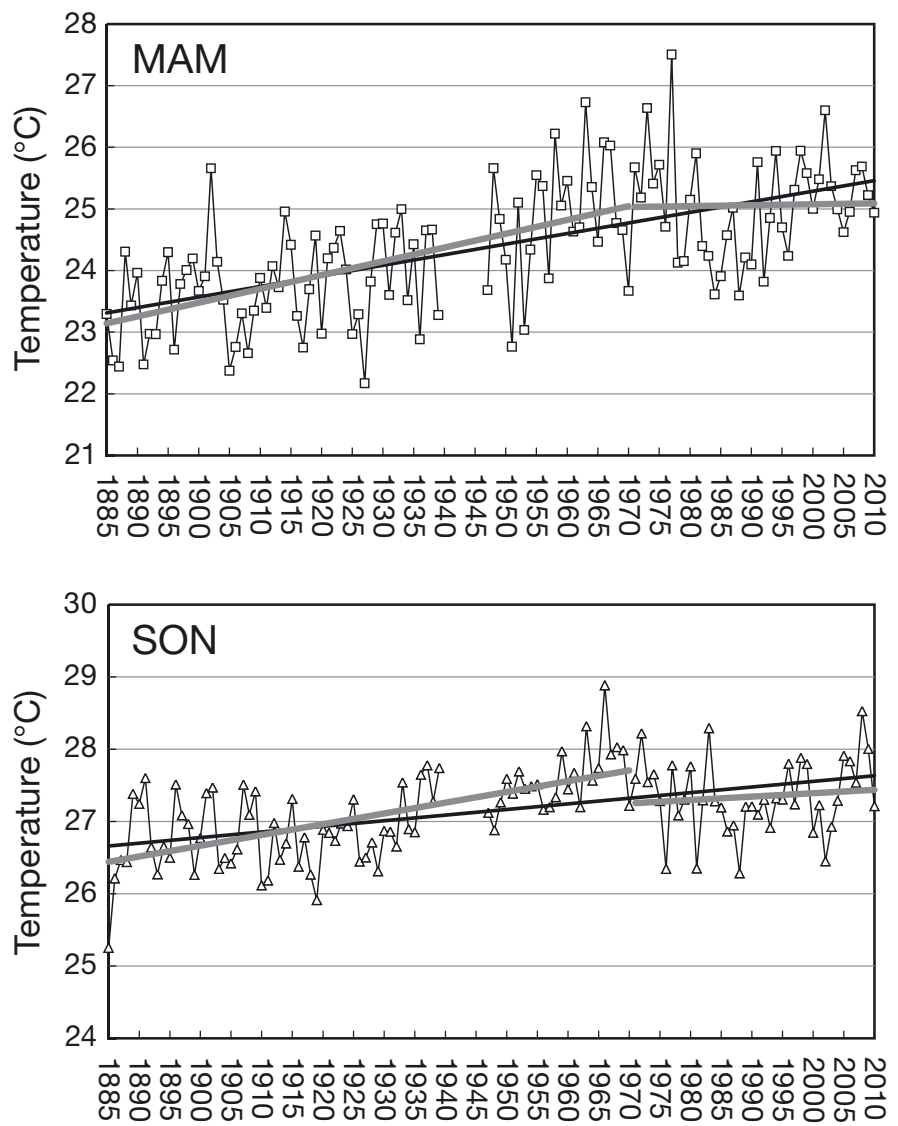

Fig. 2. Trends of seasonal mean maximum temperature $\left(\mathrm{T}_{\mathrm{Max}}\right)$ in Hong Kong in 4 seasons (winter: DJF, spring: MAM, summer: JJA, autumn: SON) from 1885-2010. Trends for the sub-periods 1885-1970 and 1971-2010 are also plotted in grey for comparison. Data not available during 1940-1946 due to World War II 

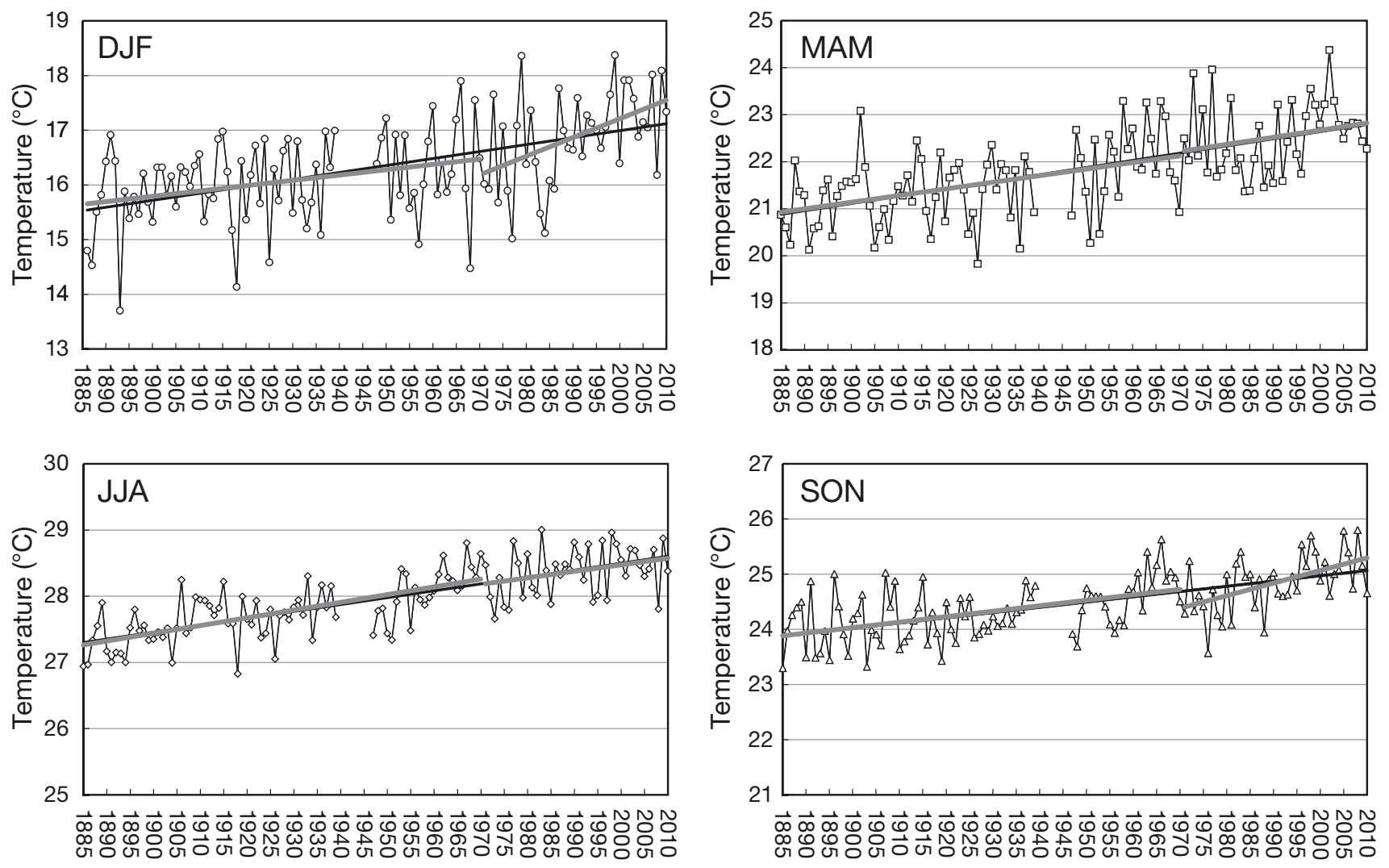

Fig. 3. As in Fig. 2, for seasonal average mean temperature $\left(\mathrm{T}_{\text {Mean }}\right)$

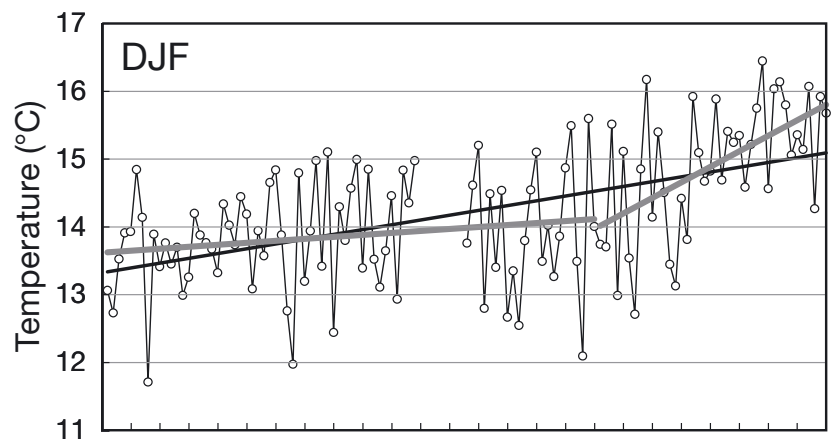

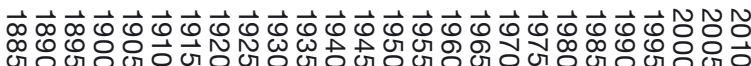

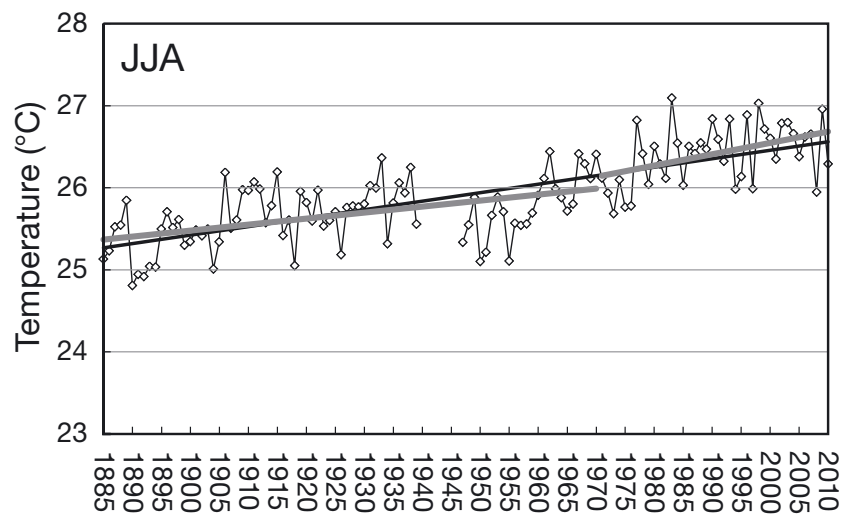

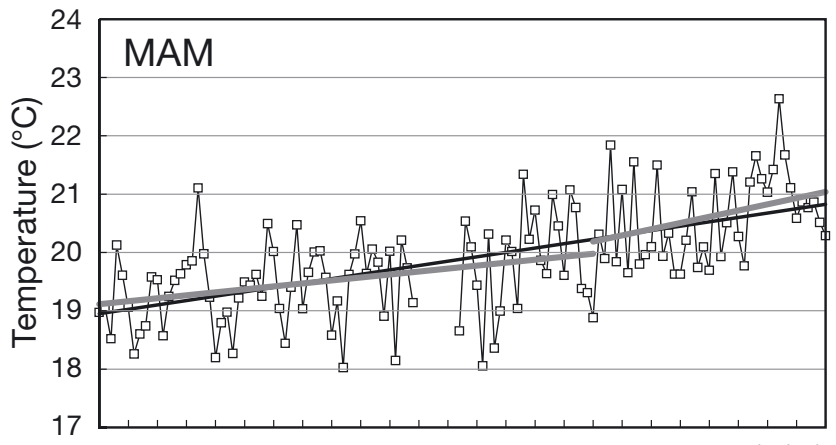

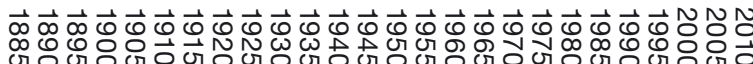

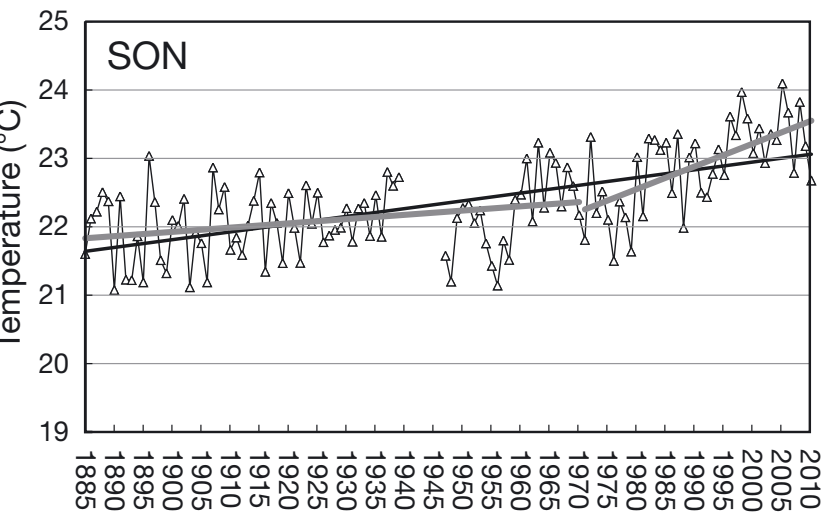

Fig. 4. As in Fig. 2, for seasonal mean minimum temperature $\left(\mathrm{T}_{\mathrm{Min}}\right)$ 
Table 1. Trends of $\mathrm{T}_{\text {Max }}, \mathrm{T}_{\text {Mean }}$, and $\mathrm{T}_{\text {Min }}$, extreme temperature indices (TX10p, TN10p, TX90p, TN90p), and the cooling degree-days (CDD) and heating degree-days (HDD) of Hong Kong in 4 seasons (winter: DJF, spring: MAM, summer: JJA, autumn: SON) from 1885-2010. There were no CDD (HDD) in winter (summer) during the study period. All values (except that for HDD in SON) are statistically significant at $5 \%$ level

\begin{tabular}{|lcccccccccc|}
\hline & \multicolumn{3}{c}{ Temperature } & \multicolumn{4}{c}{ Extreme temperature indices } & \multicolumn{2}{c|}{ Degree-days } \\
& $\mathrm{T}_{\text {Max }}$ & $\mathrm{T}_{\text {Mean }}$ & $\mathrm{T}_{\text {Min }}$ & \multicolumn{1}{c}{ TX10p TN10p } & TX90p & TN90p & CDD & HDD \\
\hline DJF & 0.12 & 0.13 & 0.14 & -0.85 & -0.88 & 0.80 & 1.15 & - & -0.74 \\
MAM & 0.17 & 0.15 & 0.15 & -1.21 & -1.09 & 0.92 & 0.98 & 0.15 & -0.30 \\
JJA & 0.10 & 0.10 & 0.10 & -0.66 & -1.08 & 0.92 & 1.13 & 0.91 & - \\
SON & 0.08 & 0.10 & 0.11 & -0.66 & -1.04 & 0.70 & 1.20 & 0.32 & -0.02 \\
Annual & 0.12 & 0.12 & 0.13 & -0.72 & -0.97 & 0.81 & 1.11 & 1.38 & -1.03 \\
\hline
\end{tabular}

We found no significant trend in the last few decades in all seasons from 1971-2010. Analysis of the trends of $\mathrm{T}_{\text {Max }}, \mathrm{T}_{\text {Mean }}$, and $\mathrm{T}_{\text {Min }}$ of Hong Kong on a monthly basis suggests that among the 12 months, February and March have the most significant increasing trends, which are almost double those of the other months (figure not shown).

\subsection{Extreme temperature indices and HDD/CDD}

The trends of the 4 extreme temperature indices (TX10p, TN10p, TX90p, TN90p) for Hong Kong in the 4 seasons during the period 1885-2010 are summarized in Table 1. All trends were statistically significant at the $5 \%$ level. The hot indices, TN90p (extremely high minimum temperature) and TX90p (extremely high maximum temperature), increased in all seasons, and the increasing trend of TN90p was larger than that of TX90p. On the other hand, the cold indices, TN10p and TX10p, decreased in all seasons, and the decreasing trend of TN10p was larger than that of TX10p. This implies that the frequencies of extremely high minimum and maximum temperature increased, while the frequencies of extremely low minimum and maximum temperature decreased in the study period.

The trends of CDD and HDD for Hong Kong in 4 seasons during the period 1885-2010 are summarized in Table 1. No CDD in winter (DJF) and no HDD in summer (JJA) were recorded during the study period. The trend of CDD in spring, summer, and autumn was increasing, while the trend of HDD in spring, autumn, and winter was decreasing. All trends were statistically significant at the $5 \%$ level except the trend of HDD in autumn. JJA and DJF, respectively, had the highest increasing rate in CDD and the highest decreasing rate in HDD amongst the seasons. These changes in the cooling demand and heating demand align well with the long-term increasing trend of the Hong Kong temperature during the study period.

\subsection{Cool and hot periods}

The length and persistence of the cool and hot periods in a year are also good indicators for assessing the changing climate. As described in Section 2.4, a 'cool (hot) day' is defined as a day with daily mean temperature $\leq 18.8^{\circ} \mathrm{C} \quad\left(\geq 27.7^{\circ} \mathrm{C}\right)$. Since all cool (hot) days occurred between October and May (April and October) during the period from 1885-2010 (see Figs. 5a \& 6a), the cool (hot) period in a year is defined as the time period between the first and last occurrence of the cool (hot) day during October-May in the following year (April-October in the same year). Fig. 5 shows the distribution and the trend of the annual number of 'cool days' during October-May in 1885-2010. Fig. 6

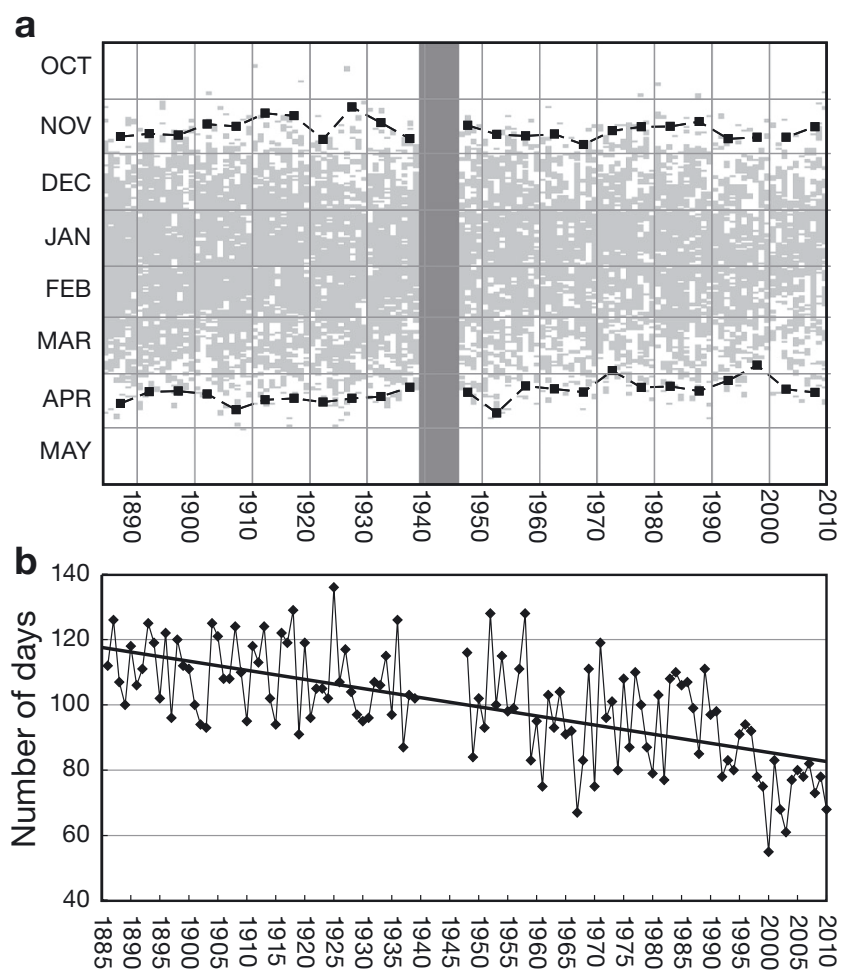

Fig. 5. (a) Distribution of cool days from October to May in 1885-2010. Dashed lines: 5 yr mean of the start and end dates of the cool period. (b) Trend in cool days from October to May in 1885-2010. The trend is statistically significant at the $5 \%$ level. Data not available during 1940-1946 due to World War II 


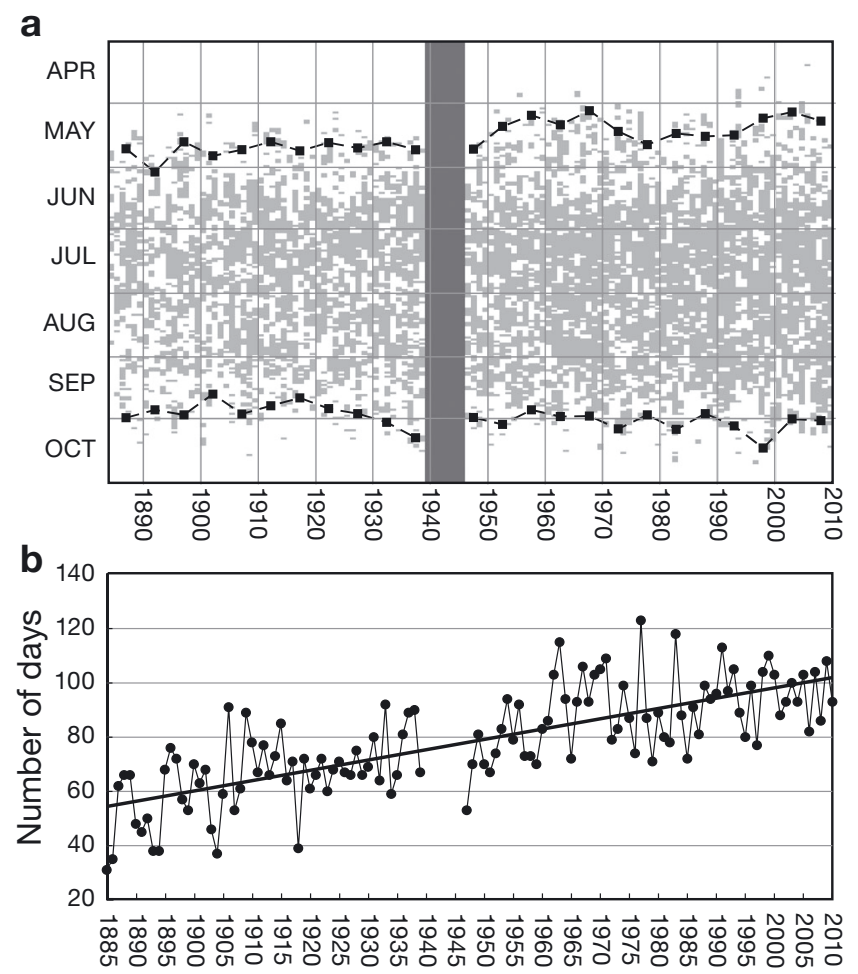

Fig. 6. (a) Distribution of hot days from April to October in 1885-2010. Dashed lines: 5 yr mean of the start and end dates of the hot period. (b) Trend in hot days from April to October in 1885-2010. The trend is statistically significant at the 5\% level. Data not available during 1940-1946 due to World War II

shows the distribution and the trend of the annual number 'hot days' during April-October in 18852010. The number of cool days had a significant decreasing trend with a decreasing rate of $2.8 \mathrm{~d}$ decade $^{-1}$, while the number of hot days increased at a rate of $3.8 \mathrm{~d} \mathrm{decade}^{-1}$. Analysis of the length of the cool (hot) period also showed a statistically significant decreasing (increasing) trend (figures not shown). Also, the ratio between the number of cool (hot) days and the total number of days within the cool (hot) period decreased (increased). Both suggest that the cool (hot) period has become shorter (longer) over the last century.

\subsection{Possible causes of the changes}

The HKOHq is located in the heart of urban Kowloon, where city development has been very active over the last few decades. The observed increase in the temperature recorded at HKOHq can be attributed to global warming caused by an enhanced greenhouse effect and also a local urbanization effect
(Leung et al. 2004, Lee et al. 2006, Wu et al. 2008, Ginn et al. 2010). Urbanization can strongly affect nocturnal temperatures, and its effect on minimum temperature is also more significant than on the maximum temperature (Karl et al. 1993, Kusaka \& Kimura 2004, Zhou et al. 2004). Similar studies for other cities in China have also suggested that the urbanization effect has made a discernible contribution to the observed warming trend in the last few decades (Zhou et al. 2004, He et al. 2007, Ren et al. 2008, Dou \& Zhao 2011).

The lack of a rising trend in $\mathrm{T}_{\text {Max }}$ over the last few decades may firstly be due to the significant increase in cloud amount and decrease in solar radiation in Hong Kong since the 1970s (Ginn et al. 2010). One potential cause of the increase in cloud amount over Hong Kong could be an increase in the concentration of condensation nuclei in the air that favors the formation of clouds, which is known to be associated with urbanization and human activities in the region. The increased concentration of suspended particulates also further reduces solar radiation reaching the ground, dampening the rise in daytime temperatures (Wild et al. 2007, Zhang et al. 2009, Wang et al. 2011). Secondly, the daytime shading effect by tall buildings near HKOHq could also partly block solar radiation reaching the ground and may affect the daytime temperature profile.

To estimate the contribution of the local urbanization effect to the increase in temperature, the method of comparing the temperature of a rural station to that of an urban station has been widely used (Karl et al. 1988, Arnfield 2003, Ren et al. 2008). Rural stations in Hong Kong with a sufficiently long time series of records for trend studies are lacking. Although the weather station at Waglan Island has a reasonably long data period, this is an offshore island station which is not suitable for UHI studies, as its temperature is modulated by nearby sea surface temperature most of the time (Sakakibara \& Owa 2005). We used Macao, a station located west of the Pearl River Estuary and about $65 \mathrm{~km}$ from Hong Kong, as the rural station in this study. According to a recent study by Fong et al. (2010), the long-term temperature observations at Macao are relatively less affected by the urbanization effect and could be considered a suitable rural station for urbanization studies in southern China. Moreover, the distance between Macao and Hong Kong is well within the recommended distance $(30-100 \mathrm{~km})$ for UHI studies as suggested by Karl et al. (1988). As hourly observations for Macao are available since 1952 and there are noticeable developments after 2002 (DSEC 2010), 
data from Macao and HKOHq between 1952 and 2002 were used for the estimation. During this period, the warming trend of Macao's annual mean temperature was $0.07^{\circ} \mathrm{C}$ decade ${ }^{-1}$, which is about $48 \%$ that of $\mathrm{HKOHq}\left(0.15^{\circ} \mathrm{C}\right.$ decade $\left.^{-1}\right)$. The difference in the trends is larger in winter and spring, suggesting more contribution from urbanization in these 2 seasons (Table 2).

Besides the urban minus rural station approach, another method proposed by Dou \& Zhao (2011) was also adopted here to assess the contribution of the urbanization effect to the warming trend of Hong Kong. This approach uses the NCEP reanalysis temperature data and the upper air sounding temperature data at the $850 \mathrm{hPa}$ level to compute the background temperature. Details of the computing method are provided in Appendix 1. Based on this method, the background warming trend near Hong Kong (i.e. without urbanization) from $1971-2010$ was about $0.12^{\circ} \mathrm{C}$ decade $^{-1}$. Subtracting this from the observed trend of $0.21^{\circ} \mathrm{C}$ decade $^{-1}$ yields the estimated contribution of urbanization to the warming trend of about $0.09^{\circ} \mathrm{C}_{\text {decade }}{ }^{-1}$ (about $42.3 \%$ ). From a seasonal perspective, this method also shows that the contribution of urbanization to the warming trend was larger in winter and spring (Table 3). We note that, in summer, the background increasing trend was slightly higher than that of the surface observations.

Based on the estimations above using 2 different approaches, the urbanization effect is estimated to have contributed on average about 40 to $50 \%$ of the increasing temperature trend in Hong Kong over the last few decades.

Apart from the urbanization effect mentioned above, the relatively higher rate of temperature increase in spring and winter (Table 1) may be partly attributed to the weakening of the winter monsoon in East Asia in the last few decades. The strength of the winter monsoon, usually represented by winter monsoon indices, is negatively correlated with the winter

Table 2. Trends of $\mathrm{T}_{\text {Mean }}$ in Hong Kong and Macao in 4 seasons (winter: DJF, spring: MAM, summer: JJA, autumn: SON) in 1952-2002 and their differences. Bold: statistically significant at the $5 \%$ level

\begin{tabular}{|c|c|c|c|c|c|}
\hline & \multicolumn{2}{|c|}{ _Hong Kong _ـ } & \multicolumn{2}{|c|}{ Macao-_ } & \multirow{2}{*}{$\begin{array}{c}\text { Differences in trend } \\
\text { (Hong Kong - Macao) } \\
\left({ }^{\circ} \mathrm{C} \text { decade }{ }^{-1}\right)\end{array}$} \\
\hline & $\begin{array}{l}\mathrm{T}_{\text {Mean }} \\
\left({ }^{\circ} \mathrm{C}\right)\end{array}$ & $\begin{array}{c}\text { Trend } \\
\left({ }^{\circ} \mathrm{C} \text { decade }^{-1}\right)\end{array}$ & $\begin{array}{l}\mathrm{T}_{\text {Mean }} \\
\left({ }^{\circ} \mathrm{C}\right)\end{array}$ & $\begin{array}{c}\text { Trend } \\
\left({ }^{\circ} \mathrm{C} \text { decade }^{-1}\right)\end{array}$ & \\
\hline DJF & 16.6 & 0.27 & 15.5 & 0.16 & 0.10 \\
\hline MAM & 22.3 & 0.15 & 22.0 & 0.05 & 0.10 \\
\hline JJA & 28.3 & 0.09 & 28.2 & 0.05 & 0.04 \\
\hline SON & 24.7 & 0.11 & 24.2 & 0.06 & 0.04 \\
\hline Annual & 23.0 & 0.15 & 21.8 & 0.07 & 0.07 \\
\hline
\end{tabular}

Table 3. Comparison of the observed trends of $\mathrm{T}_{\text {Mean }}\left({ }^{\circ} \mathrm{C}\right.$ decade $^{-1}$ ) in Hong Kong and the background warming trend in Hong Kong in 4 seasons (winter: DJF, spring: MAM, summer: JJA, autumn: SON) in 1971-2010. Bold: statistically significant at the $5 \%$ level

\begin{tabular}{|lccc|}
\hline & Observed & $\begin{array}{c}\text { Background } \\
\text { warming }\end{array}$ & $\begin{array}{c}\text { Observed - } \\
\text { background }\end{array}$ \\
\hline DJF & $\mathbf{0 . 3 4}$ & 0.19 & $\mathbf{0 . 1 5}$ \\
MAM & 0.15 & 0.01 & 0.14 \\
JJA & $\mathbf{0 . 1 0}$ & 0.07 & 0.03 \\
SON & $\mathbf{0 . 2 3}$ & $\mathbf{0 . 1 9}$ & 0.04 \\
Annual & $\mathbf{0 . 2 1}$ & $\mathbf{0 . 1 2}$ & $\mathbf{0 . 0 9}$ \\
\hline
\end{tabular}

air temperature in China (Liu et al. 2008, Zhu 2008). Studies conducted by Xu et al. (2006) and Guo et al. (2010) have shown that the surface winds in China associated with the East Asian winter monsoon have decreased significantly since 1969. As the East Asian monsoon is mainly driven by the differential heating between land and ocean, the weakening of the East Asian winter monsoon winds may be partly associated with global warming, which has caused significant warming over northern China in the second half of the 20th century and has weakened the pressure gradient between the land and the oceans. Such impacts of global warming on the East Asian winter monsoon have also been demonstrated by studies using coupled atmosphere-ocean general circulation models (Hu et al. 2000, Hori \& Ueda 2006).

\section{CONCLUSION}

Our analysis of temperature observations at HKOHq from 1885-2010 has revealed that the $\mathrm{T}_{\text {Max }}$ $\mathrm{T}_{\text {Mean }}$, and $\mathrm{T}_{\mathrm{Min}}$ of Hong Kong show significant longterm increasing trends in all 4 seasons and that the warming trend is more prominent in winter and spring. This is in general consistent with the warming trend in southern China and Macao reported in other studies (Guangdong Provincial Meteorological Bureau 2007, Fong et al. 2010).

For extreme indices, we observed a significant increase in the hot indices (TN90p and TX90p) and a significant decrease in the cold indices (TX10p and TN10p) in all seasons. The seasonal variations of the HDD and CDD also indicate that $\mathrm{CDD}$ has a significant increasing trend while HDD has a decreasing trend. The analysis of the hot 
and cool periods in Hong Kong showed that the number of cool days is decreasing significantly at a rate of about $2.8 \mathrm{~d} \mathrm{decade}^{-1}$, while the number of hot days is increasing significantly at the rate $3.8 \mathrm{~d}_{\text {decade }}{ }^{-1}$. Moreover, the cool (hot) period has become significantly shorter (longer) over the last century.

Since the HKOHq is located at the heart of the urban area, the observed changes in the temperatures over the past century are likely attributable to both global climate change and local urbanization. Our attempt to estimate the contribution of the urbanization effect to the observed warming using 2 different approaches suggests that about 40 to $50 \%$ of the warming in the last few decades could be explained by local urbanization and that the proportion is relatively higher in winter and spring. In addition to the urbanization effect, the relatively higher rate of temperature increase in spring and winter could also be partly attributed to the weakening of the winter monsoon in East Asia over the last few decades.

Acknowledgements. We acknowledge NOAA/OAR/ESRL PSD (Boulder, CO, USA) for providing NCEP Reanalysis 1 data on their web site at www.esrl.noaa.gov/psd/. Observational data from Macao were provided by the Macao Meteorological and Geophysical Bureau. We also thank colleagues at the Hong Kong Observatory: C. M. Shun, H. Lam, E. W. L. Ginn, and H. Y. Mok, as well as the 2 anonymous reviewers for their useful comments on the manuscript.

\section{LITERATURE CITED}

Arnfield AJ (2003) Two decades of urban climate research: a review of turbulence, exchanges of energy and water, and the urban heat island. Int J Climatol 23:1-26

Christidis N, Stott PA, Brown SJ (2011) The role of human activity in the recent warming of extremely warm daytime temperatures. J Clim 24:1922-19301

> Day AR, Karayiannis TG (1999) A new degree-day model for estimating energy demand in buildings. Build Serv Eng Res Tech 20:173-178

Ding YH, Ren GY, Shi GY, Gong P and others (2007) China's National Assessment Report on Climate Change. I. Climate change in China and the future trend. Adv Clim Change Res 3(Suppl):1-5 (http://www.climatechange. $\mathrm{cn} / \mathrm{CN} / \mathrm{abstract/abstract8379.shtml)}$

> Dou HY, Zhao XY (2011) Climate change and its human dimensions based on GIS and meteorological statistics in Pearl River Delta, Southern China. Meteorol Appl 18: 111-122

DSEC (Direcção dos Serviços de Estatística e Censos: Statistics and Census Service, Macao SAR Government, China) (2010) Yearbook of statistics 2009. Available at www.dsec.gov.mo/getAttachment/7c6ec555-4dba-440d8992-251e3c6e7949/E_AE_PUB_2009_Y.aspx

Easterling DR, Horton B, Jones PD, Peterson TC and others (1997) Maximum and minimum temperature trends for the globe. Science 277:364-367

Eto JH (1988) On using degree-days to account for the effects of weather on annual energy use in office buildings. Energy Build 12:113-127

Fong S, Wu C, Wang A, He X and others (2010) Analysis of surface air temperature change in Macao during 19012007. Adv Clim Change Res 1:84-90

Frich P, Alexander LV, Della-Marta P, Gleason B, Haylock M, Klein Tank AMG, Peterson T (2002) Observed coherent changes in climatic extremes during the second half of the twentieth century. Clim Res 19:193-212

Ginn WL, Lee TC, Chan KY (2010) Past and future changes in the climate of Hong Kong. Acta Meteorol Sin 24:163-175

Guangdong Provincial Meteorological Bureau (2007) Assessment report on climate change of Guangdong (Selection). Guangdong Meteorol 29:1-14

Guo H, Xu M, Hu Q (2011) Changes in near-surface wind speed in China: 1969-2005. Int J Climatol 31:349-358

Hansen J, Johnson D, Lacis A, Lebedeff S, Lee P, Rind D, Russell G (1981) Climate impact of increasing atmospheric carbon dioxide. Science 213:957-966

> He JF, Liu JY, Zhuang DF, Zhang W, Liu ML (2007) Assessing the effect of land use/land cover change on the change of urban heat island intensity. Theor Appl Climatol 90:217-226

Hong Kong Observatory (2011) Summary of meteorological and tidal observations in Hong Kong 2010. Hong Kong Observatory

Hori ME, Ueda H (2006) Impact of global warming on the East Asian winter monsoon as revealed by nine coupled atmosphere-ocean GCMs. Geophys Res Lett 33:L03713, doi:10.1029/2005GL024961

Houghton JT (2009) Global warming: the complete briefing. Cambridge University Press, Cambridge

> Hu ZZ, Bengtsson L, Arpe K (2000) Impact of global warming on the Asian winter monsoon in a coupled GCM. J Geophys Res 105(D4):4607-4624

IPCC (Intergovernmental Panel on Climate Change) (2007a) Climate change 2007: the physical science basis. Contribution of Working Group I to the Fourth Assessment Report of the Intergovernmental Panel on Climate Change. Solomon S, Qin D, Manning M, Chen Z and others (eds). Cambridge University Press, Cambridge

IPCC (2007b) Summary for policymakers. In: Parry ML, Canziani OF, Palutikof JP, van der Linden PJ, Hanson CE (eds) Climate change 2007: impacts, adaptation and vulnerability. Contribution of Working Group II to the Fourth Assessment Report of the Intergovernmental Panel on Climate Change. Cambridge University Press, Cambridge, p 7-22

Jones GS, Christidis N, Stott PA (2011) Detecting the influence of fossil fuel and bio-fuel black carbon aerosols on near surface temperature changes. Atmos Chem Phys 11: 799-816

Kalnay E, Kanamitsu M, Kistler R, Collins W and others (1996) The NCEP/NCAR 40-year reanalysis project. Bull Am Meteorol Soc 77:437-471

> Karl TR, Diaz HF, Kukla G (1988) Urbanization: its detection and effect in the United States climate record. J Clim 1: 1099-1123

> Karl TR, Knight RW, Gallo KP, Peterson TC and others (1993) A new perspective on recent global warming: asymmetric trends of daily maximum and minimum temperature. Bull Am Meteorol Soc 74:1007-1023

> Kusaka H, Kimura F (2004) Thermal effects of urban canyon 
structure on the nocturnal heat island: numerical experiment using a mesoscale model coupled with an urban canopy model. J Appl Meteorol 43:1899-1910

Lacis AA, Schmidt GA, Rind D, Ruedy RA (2010) Atmospheric $\mathrm{CO}_{2}$ : principal control knob governing earth's temperature. Science 330:356-359

Lam JC (1995) Degree-day climate parameters for Hong Kong. Int J Ambient Energy 16:209-218

Lee TC, Leung WM, Chan KW (2006) Climatological normals for Hong Kong 1971-2000. Tech Note (Local) 83. Hong Kong Observatory

Lee TC, Chan HS, Ginn EWL, Wong MC (2011) Long-term trends in extreme temperatures in Hong Kong and southern China. Adv Atmos Sci 28:147-157

Leung YK, Yeung KH, Ginn EWL, Leung WM (2004) Climate change in Hong Kong. Tech Note (Local) 107. Hong Kong Observatory,

Li Z, Yan ZW (2009) Homogenized daily mean/maximum/ minimum temperature series for China from 1960-2008. Atmos Ocean Sci Lett 2:237-243

Li Q, Zhang H, Liu X, Huang J (2004) Urban heat island effect on annual mean temperature during the last 50 years in China. Theor Appl Climatol 79:165-174

Liu Y, Peng ZC, Chen T, Wei GJ and others (2008) The decline of winter monsoon velocity in the South China Sea through the 20th century: evidence from the Sr/Ca records in corals. Global Planet Change 63:79-85

Ministry of Housing and Urban-Rural Development in China (2005) Design standard for energy efficiency of residential buildings in hot summer and cold winter zone. Available at www.codeofchina.com/ps/jg/201101/ 16-1158.html

Peterson TC (2005) Climate change indices. WMO Bull 54: 83-86

Peterson TC, Folland C, Gruza G, Hogg W, Mokssit A, Plummer N (2001) Report on the activities of the Working Group on Climate Change Detection and Related Rapporteurs 1998-2001. Rep WCDMP-47, WMO-TD 1071. WMO, Geneva

Pielke R Sr, Beven K, Brasseur G, Calvert J and others (2009) Climate change: the need to consider human forcings besides greenhouse gases. Eos Trans AGU 90, doi: 10.1029/2009EO450008

Ren GY, Chu ZY, Chen ZH, Ren YY (2007) Implications of temporal change in urban heat island intensity observed at Beijing and Wuhan stations. Geophys Res Lett 34: L05711, doi:10.1029/2006GL027927

Ren GY, Zhou YQ, Chu ZY, Zhou JX, Zhang AY, Guo J, Liu XF (2008) Urbanization effects on observed surface air temperature trends in North China. J Clim 21:1333-1348

Sakakibara Y, Owa K (2005) Urban-rural temperature differences in coastal cities: influence of rural sites. Int J Climatol 25:811-820

Solomon S, Plattner GK, Knutti R, Friedlingstein P (2009) Irreversible climate change due to carbon dioxide emissions. Proc Natl Acad Sci USA 106:1704-1709

Stott PA, Gillett NP, Hegerl GC, Karoly D, Stone D, Zhang X, Zwiers FW (2010) Detection and attribution of climate change: a regional perspective. Wiley Interdiscip Rev 1: 192-211

> Tang GL, Ding YH, Wang SW, Ren GY, Liu HB, Li Z (2010)
Comparative analysis of China surface air temperature series for the past 100 years. Adv Clim Change Res 1: 11-19

Valor E, Meneu V, Caselles V (2001) Daily air temperature and electricity load in Spain. J Appl Meteorol 40: 1413-1421

von Storch H, Zwiers FW (1999) Statistical analysis in climate research. Cambridge University Press, Cambridge

Wang K, Ye H, Chen F, Xiong Y, Wang C (2011) Urbanization effect on the diurnal temperature range: different roles under solar dimming and brightening. J Clim 25: 1022-1027

Wang SW, Zhu JH, Cai JN (2004) Interdecadal variability of temperature and precipitation in China since 1880. Adv Atmos Sci 21:307-313

Wei FY, Feng L (2009) Probability distribution of minimum temperature in the winter half year in China. Adv Clim Change Res 5(Suppl):1-4

Wild H, Ohmura A, Makowski K (2007) Impact of global dimming and brightening on global warming. Geophys Res Lett 34:L04702, doi:10.1029/2006GL028031

WMO (World Meteorological Organization) (2009) Guidelines on analysis of extremes in a changing climate in support of informed decisions for adaptation. Climate Data and Monitoring WCDMP-No.72. World Meteorological Organization, Geneva

WMO (2011a) WMO statement on the status of the global climate in 2010. World Meteorological Organization,

WMO (2011b) Weather extremes in a changing climate: hindsight on foresight WMO-No. 1075. World Meteorological Organization, Geneva

Wong MC, Mok HY, Lee TC (2010) Observed changes in extreme weather indices in Hong Kong. Int J Climatol 31: 2300-2311

Wu MC, Leung YK, Lui WM, Lee TC (2008) A study on the difference between urban and rural climate in Hong Kong. 22nd Guangdong-Hong Kong-Macau Seminar on Meteorological Science and Technology, Zhongshan, China. Hong Kong Observatory Reprint 745, Hong Kong (in Chinese)

Xu M, Chang C, Fu C, Qi Y, Robock A, Robinson D, Zhang H (2006) Steady decline of East Asian monsoon winds, 1969-2000: evidence from direct ground measurements of wind speed. J Geophys Res 111:D24111, doi:10.1029/ 2006JD007337

Zhai PM, Chao QC, Zou XK (2004) Progress in China's climate change study in the 20th century. J Geogr Sci 14(Suppl):3-11

Zhang DF, Zakey AS, Gao XJ, Giorgi F, Solmon F (2009) Simulation of dust aerosol and its regional feedbacks over East Asia using a regional climate model. Atmos Chem Phys 9:1095-1110

> Zhou LM, Dickinson RE, Tian YH, Fang JY, Li QX, Kaufmann RK (2004) Evidence for a significant urbanization effect on climate in China. Proc Natl Acad Sci USA 101: 9540-9544

Zhu YF (2008) An index of East Asian winter monsoon applied to the description of China's mainland winter temperature changes. Acta Meteorol Sin 22:522-529

Z Zwiers FW, Weaver AJ (2000) The causes of 20th century warming. Science 290:2081-2083 
Appendix 1. Estimation of temperature trends due to urbanization by using reanalysis data and upper air sounding data

A method proposed by Dou \& Zhao (2011) was adopted to assess the contribution of the urbanization effect to the warming trend of Hong Kong. This approach uses the United States National Centers for Environment Prediction - National Center for Atmospheric Research (NCEP-NCAR) Re-analysis 1 data (R1; Kalnay et al. 1996) and the upper air sounding temperature data of King's Park Meteorological Station (Stn 45004, Hong Kong, about $1 \mathrm{~km}$ from HKOHq) at the $850 \mathrm{hPa}$ level to compute the background temperature. Eq. (A1) shows the relation between trends of actual observations $\left(T_{\text {actual }}\right)$, temperature variation due to local urbanization $(U T)$, and background temperature variation due to other causes (BT) such as global warming from 1971-2000:

$$
T_{\text {actual }}=U T+B T
$$

$\boldsymbol{B} \boldsymbol{T}$ can be estimated by Eq. (A2):

$$
B T=T_{850}+\left(T_{N 1000}-T_{N 850}\right)
$$

$\boldsymbol{T}_{\mathbf{8 5 0}}$ is the observed temperature trend of King's Park Meteorological Station (45004) at the $850 \mathrm{hPa}$ level from 1971-2010, and $\boldsymbol{T}_{\boldsymbol{N 1 0 0 0}}$ and $\boldsymbol{T}_{\boldsymbol{N} \mathbf{8 5 0}}$ are the temperature trends of R1 data from 1971-2010 at the $1000 \mathrm{hPa}$ and $850 \mathrm{hPa}$ levels, respectively.

Editorial responsibility: Gouyu Ren, Beijing, China
Submitted: March 13, 2012; Accepted: August 31, 2012 Proofs received from author(s): November 8, 2012 